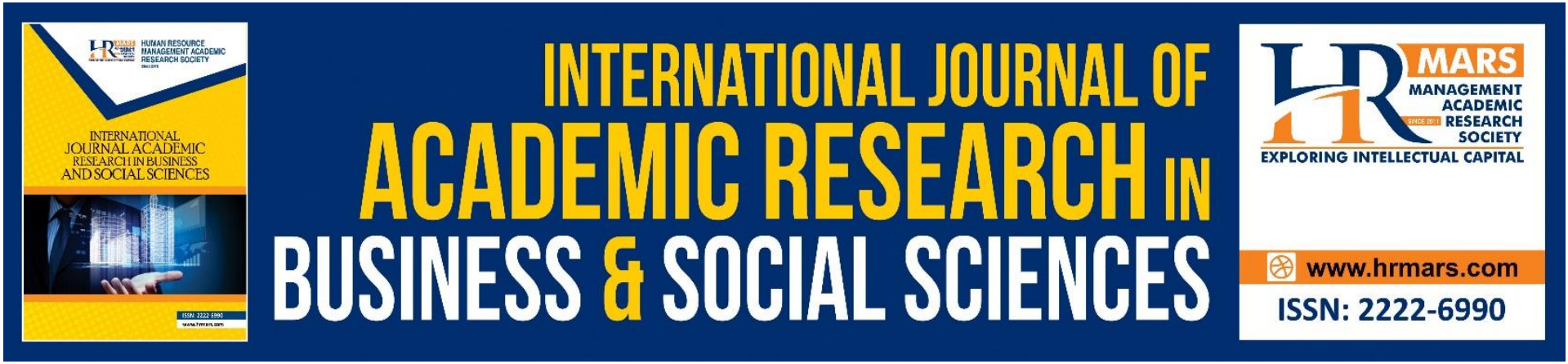

\title{
Research Trends and Opportunities of Halal Cosmetic: A Systematic Literature Review
}

Nurzalikha Aimi Mohd Subri, Wan Marhaini Wan Omar, Norzawani Mamat @ Ibrahim

To Link this Article: http://dx.doi.org/10.6007/IJARBSS/v12-i1/11912

DOI:10.6007/IJARBSS/v12-i1/11912

Received: 07 November 2021, Revised: 12 December 2021, Accepted: 28 December 2021

Published Online: 13 January 2022

In-Text Citation:(Subri et al., 2022)

To Cite this Article: Subri, N. A. M., Omar, W. M. W., \& Ibrahim, N. M. @. (2022). Research Trends and Opportunities of Halal Cosmetic: A Systematic Literature Review. International Journal of Academic Research in Business and Social Sciences, 12(1), 531 - 547.

Copyright: (c) 2022 The Author(s)

Published by Human Resource Management Academic Research Society (www.hrmars.com)

This article is published under the Creative Commons Attribution (CC BY 4.0) license. Anyone may reproduce, distribute, translate and create derivative works of this article (for both commercial and non0-commercial purposes), subject to full attribution to the original publication and authors. The full terms of this license may be seen at: http://creativecommons.org/licences/by/4.0/legalcode

Vol. 12, No. 1, 2022, Pg. $531-547$

http://hrmars.com/index.php/pages/detail/IJARBSS

Full Terms \& Conditions of access and use can be found at http://hrmars.com/index.php/pages/detail/publication-ethics 


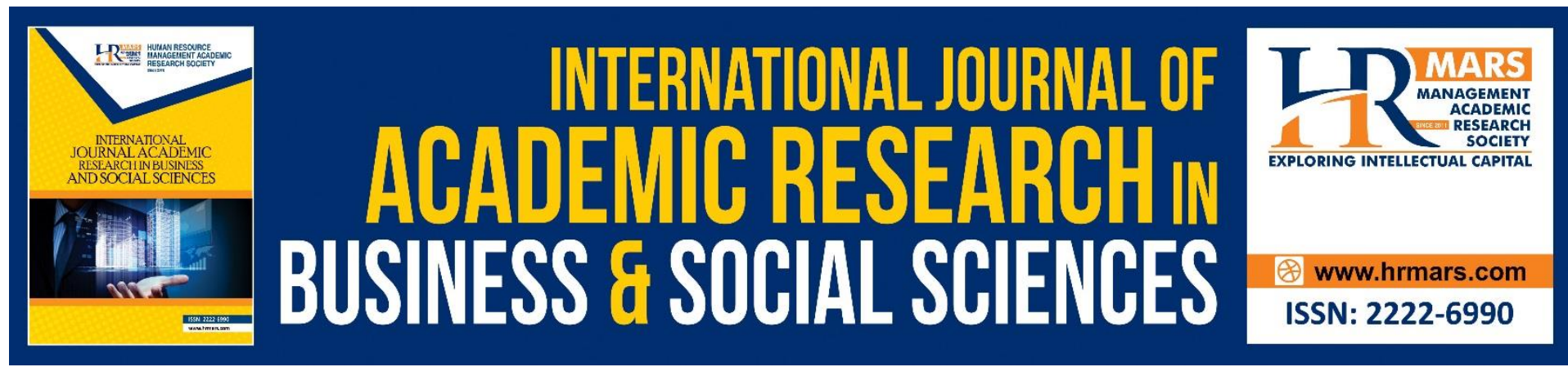

\title{
Research Trends and Opportunities of Halal Cosmetic: A Systematic Literature Review
}

\section{Nurzalikha Aimi Mohd Subri ${ }^{1}$, Wan Marhaini Wan Omar², Norzawani Mamat @ lbrahim³}

${ }^{1,2}$ Faculty of Business and Management, Universiti Teknologi Mara Cawangan Kelantan, Kampus Kota Bharu, Lembah Sireh, 15050 Kota Bharu, Kelantan, Malaysia, ${ }^{3}$ Faculty of Business and Management, Universiti Teknologi Mara Cawangan Selangor, Kampus Puncak Alam, 42300 Kuala Selangor, Selangor, Malaysia

Email:whaini299@uitm.edu.my.

\begin{abstract}
Evidence showed that Muslim and non-Muslim people nowadays look for halal cosmetics and personal care products due to their safety, high quality, hygienic preparation procedures, and integrity maintenance throughout the production stage. The objective of this study is to review halal cosmetic articles from the year 2010 to 2020 . The PRISMA Statement (Preferred Reporting Items for Systematic reviews and Meta-Analyses) review method was utilized to classify the articles in which thirty-four articles related to the study were identified. The findings showed that numerous articles were found in the Scopus database with the highest publication being conducted in Malaysia while Theory of Planned Behavior (TPB) was the most common theory discussed in halal cosmetics articles, and the most common study design was quantitative type of approach. Five main themes were generated which included purchase intention on halal cosmetics, halal cosmetics adoption, awareness on halal cosmetics, knowledge and religiosity, and halal cosmetics concept. Journal of Islamic Marketing is a popular journal publishing articles on halal cosmetics. The originality of this research is that the identified research themes were unnoticed by previous studies. Few recommendations and research directions are highlighted to enhance halal cosmetics research scope in the future.
\end{abstract}

Keywords: Halal Cosmetics, Halal, Systematic Literature Review

\section{Introduction}

The halal cosmetic industry has become an emerging industry in Muslim countries globally. The market is considered a highly competitive market, with the presence of various domestic and international players. The halal cosmetics products are widely accepted among the Muslim population since they meet their needs and give them "reassurance" (Jihan et al., 2016). Currently, there is an increasing demand for halal cosmetics products worldwide. According to Allied Market Research (2021), the global market growth for halal cosmetics is expected to grow by US\$54.16 billion in 2022. It shows that Muslim consumers are now demanding not only the high quality of the product but also the products which 
adhere to Islamic law and halal. This trend also is increased due to manufacturers in the industry had produced a variety of products to fulfil the market demand which is estimated to be 2.4 billion Muslim consumers worldwide (Abdullah et. al., 2020). Furthermore, the beauty of the ingredient in halal cosmetics is also attracting non-Muslims because they believe that halal cosmetics are more hygienic and safer to consume (Ngah et al., 2019).

Statistically, the United States is the top country in the world spending on cosmetics which is estimated at US\$78 billion, followed by the United Kingdom which expands at US\$40 billion, and Germany which spends about US\$34 billion. In truth, Muslim consumers are one of the high consumers spending on cosmetics which is estimated at US\$26 billion (Nawaz et al., 2021). By 2030, the number of Muslim populations is expected to increase by approximately 2.2 billion, accounting for the total world population of 8.3 billion. Consuming halal products for Muslims is an obligation, not just an option (Ngah et al., 2021). Besides being religious obligation for Muslim consumers, the responsiveness on environmental issues and hygiene in halal cosmetics products are also the reasons why the number of the consumers choosing halal cosmetics is massively increasing and a large Muslim population has now become loyal to halal cosmetics product (Khalid et al., 2018; Abd Rahman et al., 2015). A study by Khalid et al (2018) found that the position of halal cosmetics in the market leads towards consumer intention to purchase the halal cosmetics product. Moreover, another study by Zaki et al (2021) stated that $77 \%$ of the respondents are concerned about the content of halal cosmetics. These scholars have emphasized that the demand for halal products has now significantly increased (Mustafar et al., 2018).

Several kinds of research have been carried out on halal cosmetics. There was a study on pharmaceuticals and cosmetics manufacturers; however, the study only focused on halal transportation adoption among halal manufacturers in Malaysia (Ngah et al., 2019). Another study focused on halal cosmetics and pharmaceuticals but particularly on the adoption of halal warehousing (Ngah et al., 2019). Some studies concerning halal cosmetics and pharmaceuticals focused on ingredients, certification, and consumer behaviour at an individual level (Putri et al., 2019a). A study on systematic literature review (SLR) by Ali et al (2016) examined the existing relevant literature on the halal cosmetic which focused on consumer behaviour. Based on 19 studies of purchase intention in halal cosmetics, Ali et al. (2016) found that most of the studies were conducted in Malaysia. Meanwhile, a study by Mahmud and Jamal (2020) was concerned about consumer behavioural intention on halal cosmetics products and it was found that religiosity has a substantial influence on consumer behavioural intention. Based on the scholarly interests in the area of halal cosmetics research, the systematic literature review conducted on this research domain had found to be unobserved in previous research. Based on the above mentioned, the objectives of the study are:

- To systematically review articles based on country, year of study, type of database, theme of study, type of theory, and type of journal.

- To generate the research themes based on the finalized articles of halal cosmetics studies for a period of ten years.

Apparently, this paper has employed the PRISMA Statement (Preferred Reporting Items for Systematic reviews and Meta- Analyses) review method to review halal cosmetics articles ranging from 2010 to 2020. The remainder of this paper is organized as follows: Section 2 outline the overview of the halal cosmetic; Section 3 puts forward a research design for the study; and Section 4 highlights the findings of the study; Section 5 discusses 
the classification of halal cosmetics research themes; Section 6 highlights the discussion and future research direction; and Section 7 concludes the study.

As mentioned above, there is several research have been carried out on halal cosmetics. However, most of the study had focused on pharmaceutical and cosmetic. Hence, the SLR on halal cosmetics is highly necessary to increase the understanding on research trends and opportunities of halal cosmetics. Despite that, as the trend of halal cosmetics is new in halal industry, therefore, the findings of this research are useful to various parties like consumers, manufacturers, and logistics provider.

\section{Halal Cosmetic: An Overview}

Halal can be defined as something that follows Islamic guidelines such as the cleanliness and quality of the products (Ngah et al., 2019). Halal is also related to the religious issues of Muslims and the symbol of Islam all over the world with the quality according to the Islamic guidelines (Annabi \& Ibidapo-Obe, 2017). Despite that, halal is usually associated with food and beverages, but nowadays, it is also related to medicines and cosmetics (Ngah et al., 2019). As studied by Shahid et al (2018), the term "halal" is not limited to food only; it also focuses on non-food areas such as personal care and cosmetics, lifestyle, medicine, travel, tourism, trade, finance, entertainment, work and education. Referring to Drug and Cosmetic Act (2012), cosmetic is defined as the product used for the human body to beautify, clean, be more attractive, or cover up the flaws. There are many types of cosmetics in the market such as product for skincare, powder, lotion and others.

Halal cosmetics is a new term in the cosmetics industry, and most consumers and manufacturers of cosmetics know almost nothing about it (Ali et al., 2016). The Federal Food, Drug, and Cosmetic Act (FD\&C Act) defined cosmetics as items designed to rub, pour, sprinkle or spray, introduce or otherwise apply to the human body to clean, beautify, enhance attractiveness or change the appearance of the human body appearance. Meanwhile, halal cosmetics is defined as products that must not have any human parts, ingredients, or any part of an animal which is forbidden to Muslims. According to Syariah law, no genetically modified organism (GMO) is declared as 'najs' and halal cosmetics should not contain a forbidden element like alcohol, no contamination with non- halal during preparation, processing, manufacturing and storage; and safe for consumers (Ismail et al., 2019). The details of the halal cosmetics definition are as below (Table 1 ).

Table 1: Definition of Halal Cosmetic

\begin{tabular}{ll}
\hline Author & \multicolumn{1}{c}{ Definition } \\
\hline Suparno (2020) & $\begin{array}{l}\text { The product is not allowed to contain any harmful ingredient } \\
\text { such as alcohol and porcine. }\end{array}$ \\
\hline Ismail et al. (2019) & $\begin{array}{l}\text { The product must not contain any artificial parts, ingredients, } \\
\text { or parts prohibited from animals to Muslims. }\end{array}$ \\
\hline $\begin{array}{l}\text { Putri \& Abdinagoro } \\
\text { (2018) }\end{array}$ & $\begin{array}{l}\text { It is safe and has a high-quality guarantee because it does not } \\
\text { contain harmful elements to the body and does not contain } \\
\text { animal-derived ingredients. }\end{array}$ \\
\hline Hussin et al. (2013a) & $\begin{array}{l}\text { The product is not using equipment contaminated with Najs or } \\
\text { harmful ingredients for preparation, processing or } \\
\text { manufacturing. }\end{array}$ \\
\hline Husain et al. (2012) & The cosmetic products must be safe to consume. \\
\hline
\end{tabular}




\section{Methodology}

1. The Review Protocol - PRISMA

The study was guided by the PRISMA Statement (Preferred Reporting Items for Systematic reviews and Meta-Analyses) review protocol (Figure 1). Interestingly, PRISMA is frequently applied in the management field (Sierra-Correa \& Cantera Kintz, 2015; Shaffril et al. 2017) and it offers three unique benefits namely: 1) defining clear research questions that allow systematic research; 2) identify inclusion and exclusion criteria; and 3) allow for large databases of the scientific literature to be used within a specific time frame. Based on this review protocol, the process started with the formulation of appropriate research questions for the review. Then, the process continued with a systematic searching strategy that considered the elements of identification, screening, and eligibility. Next, a quality assessment was conducted to ensure the quality and relevancy of the articles to be reviewed. Finally, the data were abstracted for the review and the final data were analyzed and validated.

\section{Systematic Search Strategy}

The articles were identified in the main bibliographic databases which were Scopus and Web of Science (WoS). It was analyzed for a period of 10 years from 2010 to 2020. Two databases were selected for the literature search: Scopus and WoS. These databases were selected as they were among the most extensive peer-reviewed abstract and citation databases in many related disciplines such as environmental studies, interdisciplinary social sciences, social issues, development and planning and other disciplines. Moreover, Scopus and WoS have some of the largest repositories of business search and they are typically used in the systematic literature review (Durach, Wieland \& Machuca, 2014). The Publish or Perish (POP) application was used to screen and filter the articles from the databases. Referring to the prior literature, the keywords were identified for the search process.

Table 2: The search string used for the systematic review process

\begin{tabular}{ll}
\hline Database & Keyword used \\
\hline Scopus & TITLE-ABS-KEY (("Halal Cosmetic" OR “Halal Cosmetic Management" \\
& OR “HALAL cosmetic" OR “Halal COSMETIC") AND (“Halal”) AND \\
& ("Cosmetic")) \\
\hline Web of Science & TS=(("Halal Cosmetic" OR “Halal Cosmetic Management" OR "Halal \\
& COSMETIC" OR “HALAL Cosmetic") AND ("Halal”) AND ("Cosmetic")) \\
\hline
\end{tabular}

In Table 2, the search string was constructed based on the list of the identified keywords. The search was conducted using combinations of exact keywords on titles and abstracts as these were addressed by breaking down the review questions. The search strategy resulted in a total of 82 articles where 35 articles came from WoS and 47 articles were from Scopus. However, 9 records were duplicated and needed to be removed from the dataset. Then, the data were exported to an Excel spreadsheet for data cleaning and sorting. After careful inspection, another 24 articles were excluded from the dataset due to eligibility issues (Table 3). As a result, 49 articles were retained for further analysis. 
Table 3: The inclusion and exclusion criteria

\begin{tabular}{|c|c|c|}
\hline Criterion & Inclusion & Exclusion \\
\hline Literature type & Journal article & $\begin{array}{l}\text { Book series, book, } \\
\text { chapter in the book, } \\
\text { conference proceeding, } \\
\text { editorial, non-research } \\
\text { papers, review papers, } \\
\text { opinion pieces }\end{array}$ \\
\hline Language & English & Non-English \\
\hline Timeline & Between 2010 and 2020 & $<2010$ \\
\hline Indexes & $\begin{array}{l}\text { Social Science Citation Index, } \\
\text { Emerging Sources Citation Index, Art } \\
\text { and Humanities Index (Web of } \\
\text { Science) }\end{array}$ & $\begin{array}{l}\text { Science Citation } \\
\text { Indexed Expanded } \\
\text { (Web of Science) }\end{array}$ \\
\hline
\end{tabular}

\section{Quality Assessment}

With the use of the appraisal method for both qualitative and quantitative research, 49 articles were assessed by three reviewers. In the review process, the reviewers ranked the remaining articles into three quality categories namely high, moderate, and low. Articles were accepted if all reviewers agreed on them. However, if there was a disagreement among them, a fourth reviewer was invited to assess the paper (Petticrew \& Roberts, 2006). As a result, fifteen articles were removed after assessed by the reviewers and the remaining articles were eligible for further review.

\section{Data Abstraction and Analysis}

The remaining 34 articles from Scopus and WoS were evaluated and analyzed. The data were extracted by reading through the abstract. Then, the individual reviewer went through the full text to identify the appropriate themes. Researchers performed thematic analysis to identify themes related to halal cosmetics. In the process of developing the themes, the researchers discussed any inconsistencies or any ideas that could be associated with the interpretation of the data until the point of agreement was achieved on the developed themes. Next, themes were renamed accordingly, and the details were reported structurally. Furthermore, the key findings such as research designs, country of study, theory used, and type of journal were summarized (Table 4). 


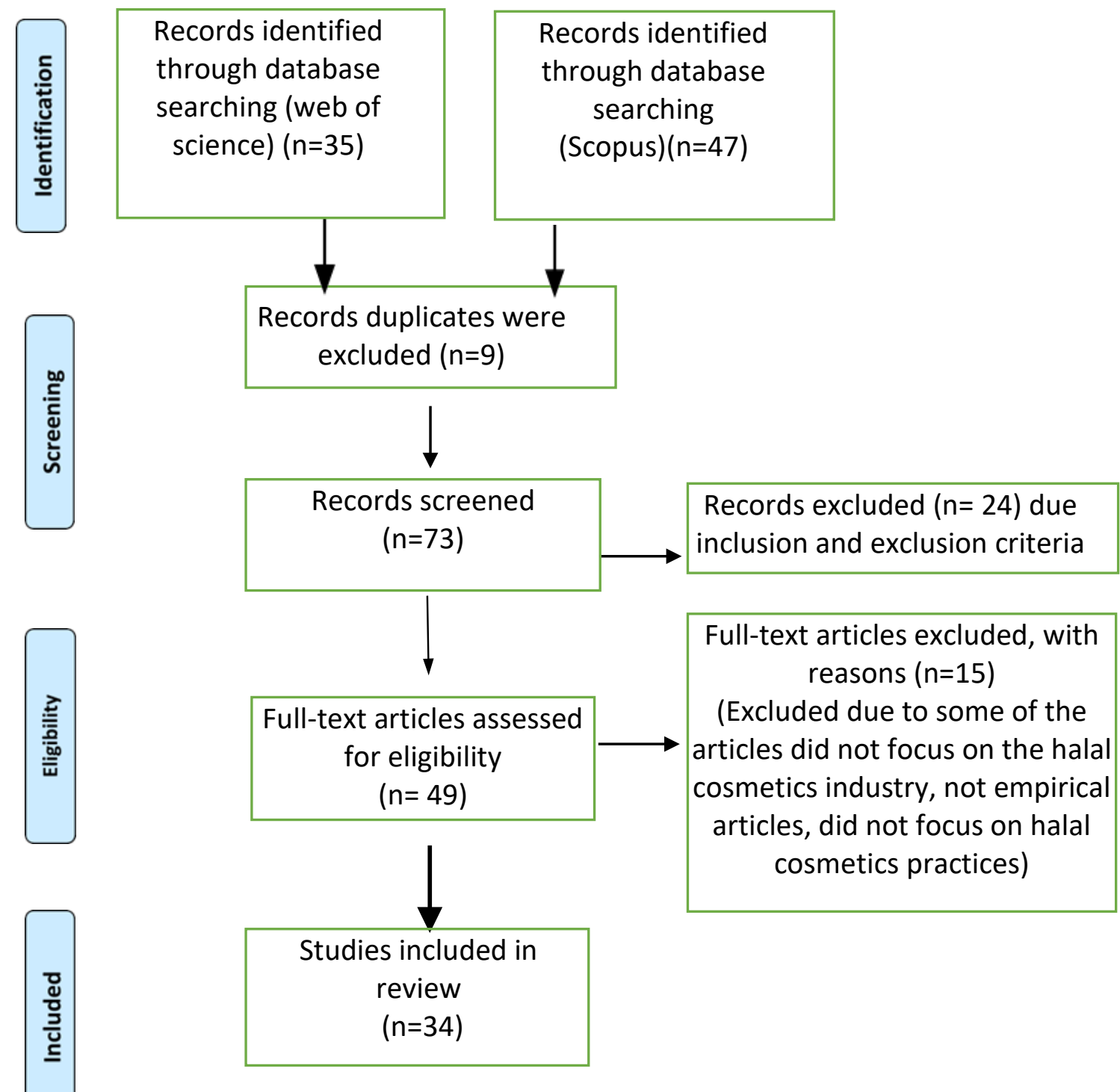

Figure 1: The flow diagram of the study is adopted from PRISMA

\section{Results}

An extensive systematic literature review showed an upward trend manifesting the increasing interest in research in the area of halal cosmetic. The result showed that 2019 had the highest number of published articles on halal cosmetics. It is then followed by the year 2020 with 8 articles (Figure 2). Halal cosmetics research area was at the early entrance of 2012 and 2013 since the number of articles published was only 1 article respectively. Based on the report of Halal Industry Development Corporation (2018), the halal industry worldwide food on the non-food industry was valued at $\$ 6.4$ trillion. Shahid et al (2018) stated that the consumer's spending on halal cosmetics rises from $\$ 27$ billion to $\$ 39$ billion. This data showed that consumers started to have awareness and intention to buy halal cosmetics. 


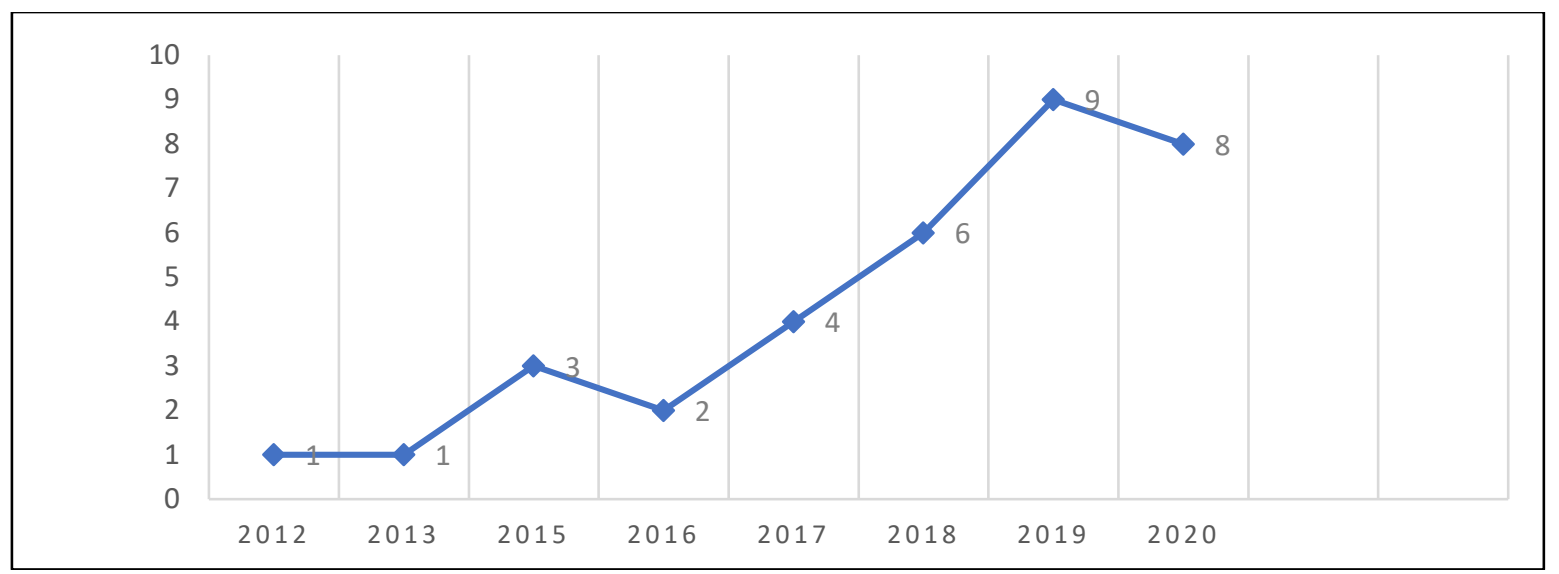

Figure 2: Publication distribution of reviewed articles by year

On the aspect of the distribution reviewed articles by country, most of the studies was from Malaysia, followed by Indonesia with 8 articles and India with 2 articles respectively. Dubai and the United Kingdom shared the same number of articles (Figure 3 ). According to the result, it showed that Malaysia had the highest rank in the research of halal cosmetics. Referring to Wei et al. (2020), Malaysia was one of the earliest countries that had awareness and moved forward to halal cosmetics. Despite this, Malaysia had developed some synchronized strategies to enhance the halal cosmetic industry such as established Halal Industry Development Corporation (HDC) to assist in developing strategies and expanding more market on the halal industry.

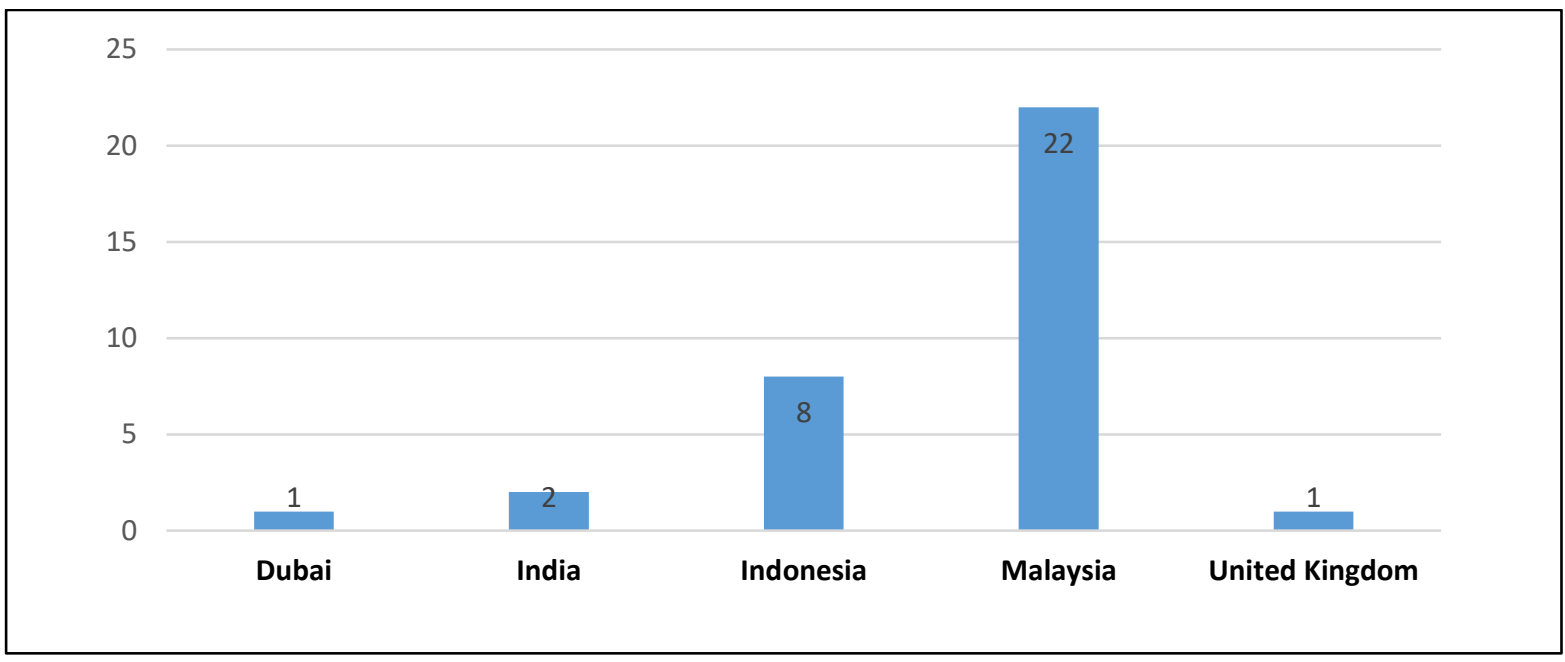

Figure 3: Publication distribution of reviewed articles by country

Meanwhile, for the application of the theory, most of the articles applied the theory of planned behaviour (TPB) to underpin the study (Figure 4). Hussin et al (2013a); Haque et al (2018); Sukesi and Akbar Hidayat (2019); Suparno (2020); Khan et al (2020) were some of the studies that used TPB theory. TPB theory is widely used particularly to examine the behaviour and intention of consumers (Maichum et al., 2016). The second theory most applied in the articles for the past 10 years was the theory of reasoned action (TRA). The studies on halal cosmetics that used TRA were conducted by (Briliana and Mursito, 2017; Sama and Trivedi, 2019; Suparno, 2020). However, not many studies on halal cosmetics 
applied the theory of consumption value (TCV). Out of 34 reviewed articles, only 1 article used TCV to explain their study.

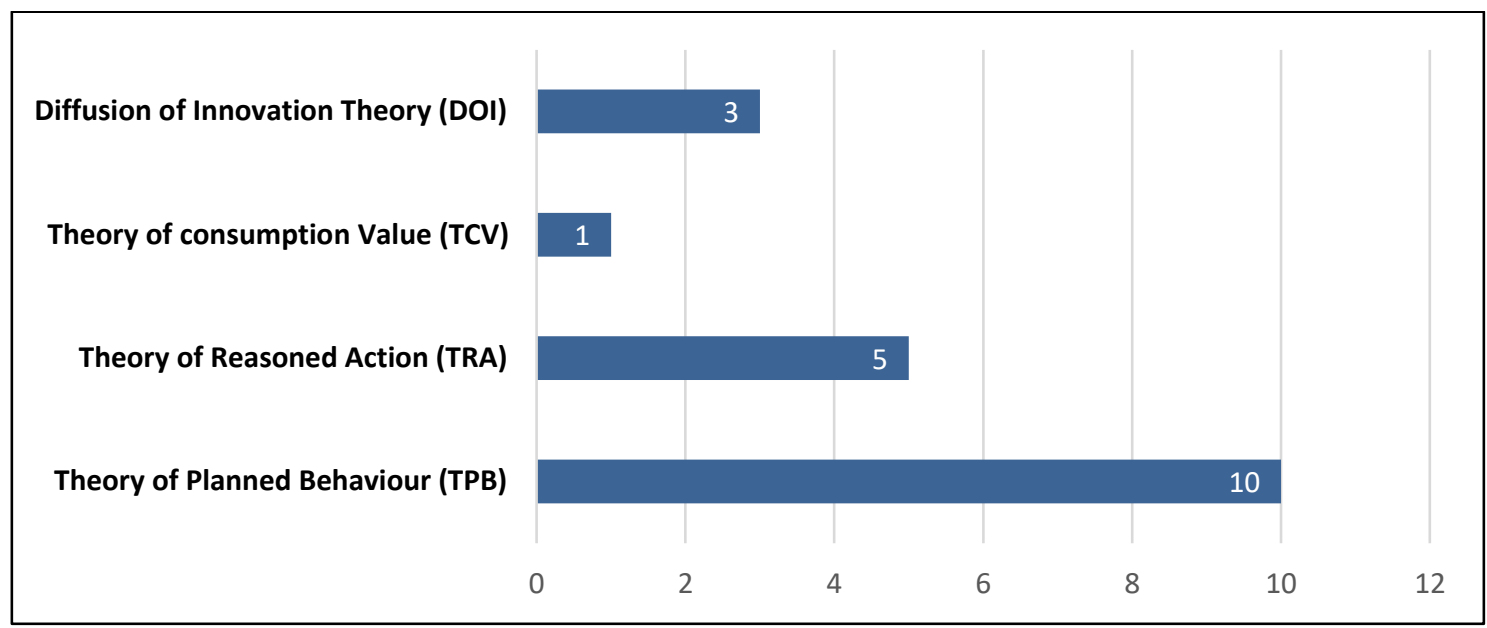

Figure 4: Publication distribution of reviewed articles by the types of underpinning theory

The distribution of research methods applied in the reviewed articles is shown in Figure 5. Approximately 24 and 9 reviewed articles used qualitative and quantitative methods respectively. Only 1 article used a mixed method in the study. The quantitative approach was popularly applied by the studies that intend to investigate the consumer purchase intention, perceived value, brand image, religious belief, and halal certification (Mustafar et al., 2018a; Handriana et al., 2020).

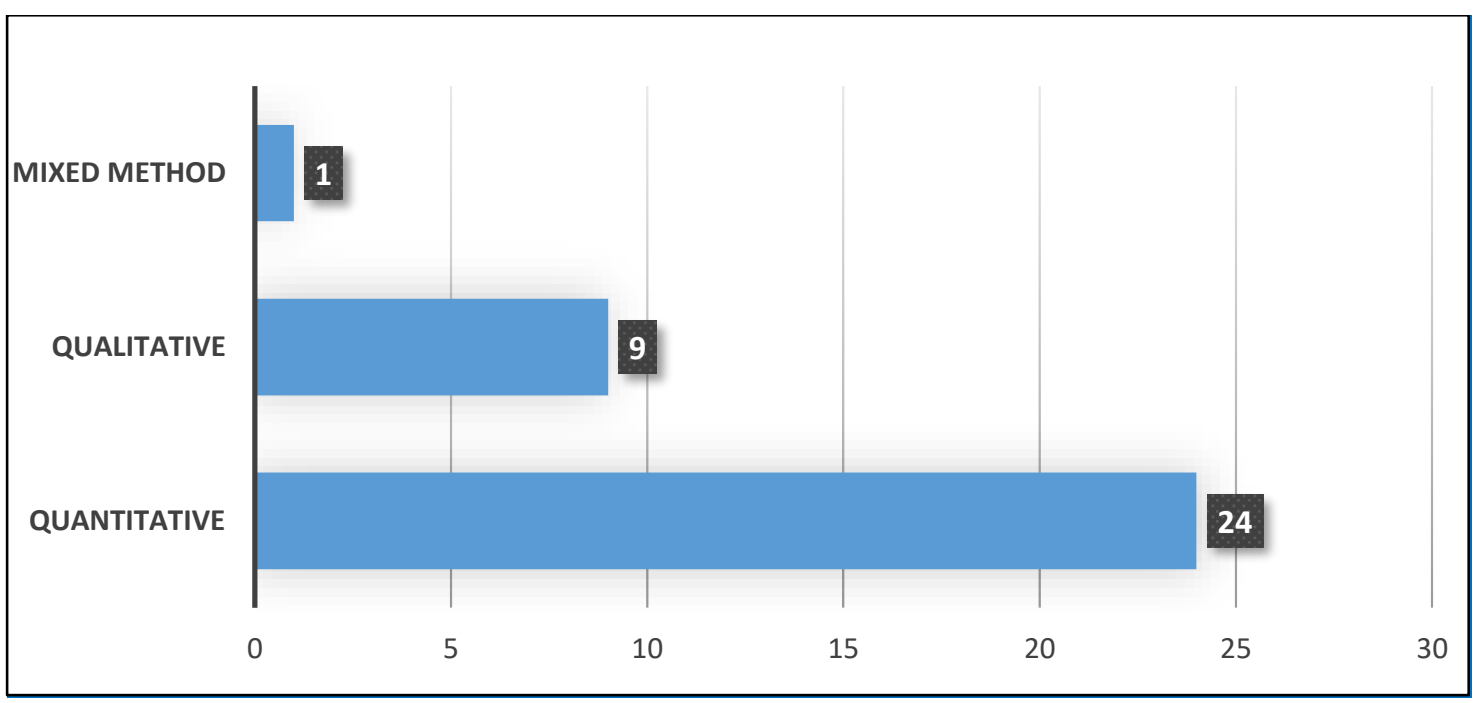

Figure 5: Publication distribution of reviewed articles by the types of methodology

The analysis of most journals published on halal cosmetics from 2010 to 2020 is shown in Figure 6. From the review, the journals that published most of the halal cosmetics articles were Journal of Islamic Marketing (JIMA) with 9 articles followed by the International Journal of Supply Chain Management with 5 articles. According to Ali et al (2019), Islamic marketing scholars were very interested to study the halal cosmetics area since the Muslim consumers are bound to use a well-known brand of personal care products as most of the products contain non-halal ingredients. 


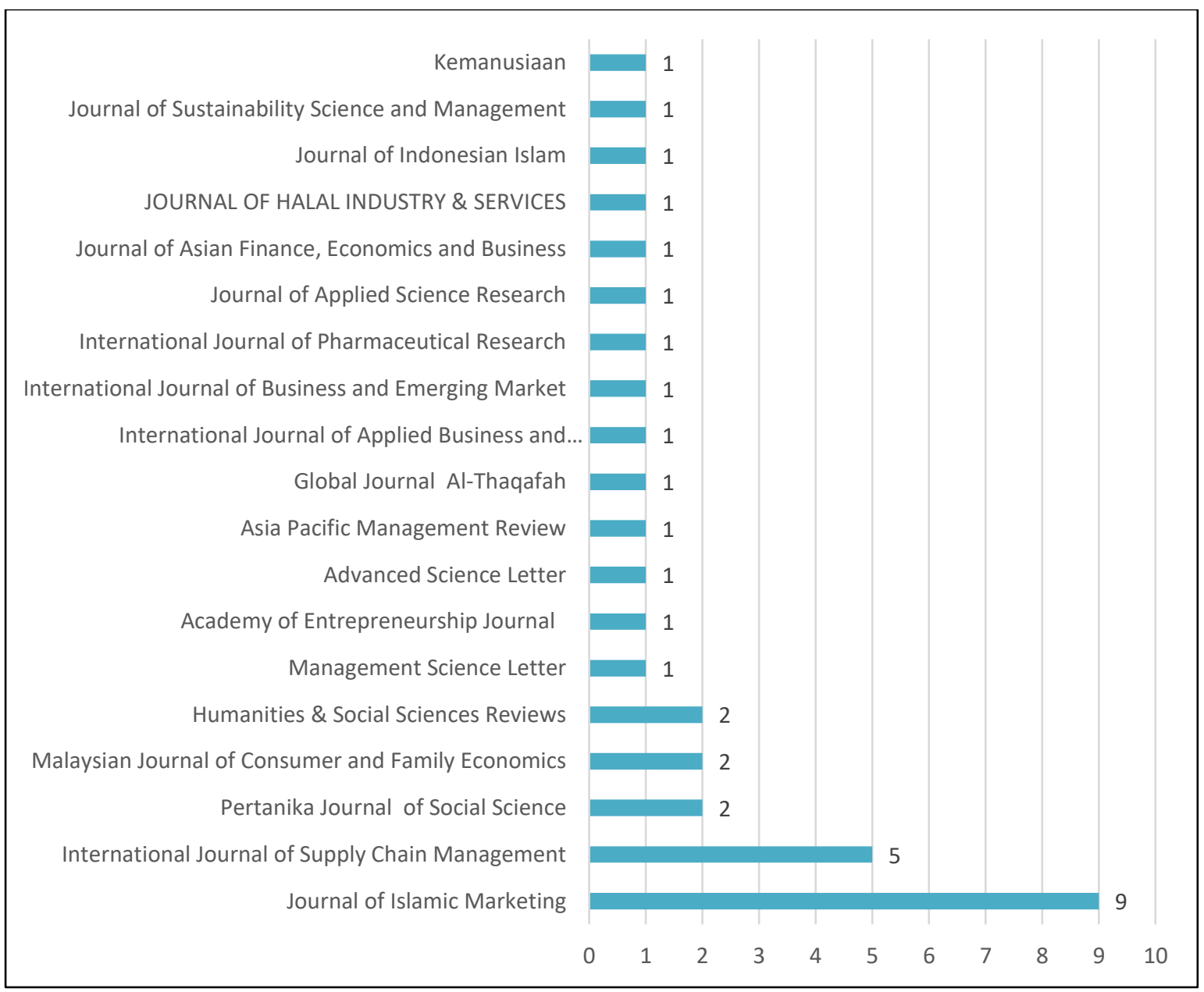

Figure 6: Publication distribution of reviewed articles by journal

\section{Classification of Halal Cosmetic Research Themes}

This section concentrates on the main themes of the studies which focused on the years of 2010 to 2020 . Thematic analysis was applied to generate the themes based on the reviewed articles. The review resulted in five main themes: purchase intention on halal cosmetics, halal cosmetic adoption, awareness of halal cosmetics, knowledge and religiosity, and halal cosmetics concept. The results provide a comprehensive analysis of current adaptation practices in the halal cosmetics industry (Figure 7). From the review, the result analysis showed that purchase intention on halal cosmetics was the highest theme used in the study with $56 \%$ of the total reviewed articles. According to Clarita et al (2020), the demand for halal cosmetics was increasing since the Muslim consumers feel comfortable and peaceful when consuming halal product in their life. Despite that, the increasing knowledge of "Halalness" among the Muslim and non-Muslim consumers was also one of the reasons in their decision making either to accept or reject the product. Meanwhile, the second-highest theme was halal adoption on halal cosmetics. According to Mohezar et al (2016), the adoption of halal cosmetics also increased due to the increase of global Muslim population and purchasing demand which created a new development of halal cosmetics.

\section{Purchase Intention on Halal Cosmetic}

A total of 19 out of 34 studies focused on the consumer's purchase intention on halal cosmetics. There were 10 studies from Malaysia, seven from Indonesia, and two studies from 
India. From the perspective of studies in Malaysia, according to Hussin et al (2013a), five factors will affect the consumer purchase intention, which are brand, price, quality, ingredients, and labelling. Meanwhile, according to Arbak et al (2019b), there is a relationship between advertisement and halal cosmetics in their studies. This is because the advertisement will affect the consumer's purchase intention to buy halal products. From their study, the negative advertisement, which included racism, sexism, intention, and language, negatively influences purchase intention. Other than that, the study of Suparno (2020) from Indonesia stated that consumer purchase intention will also affect online purchasing through shopping value and attitude.

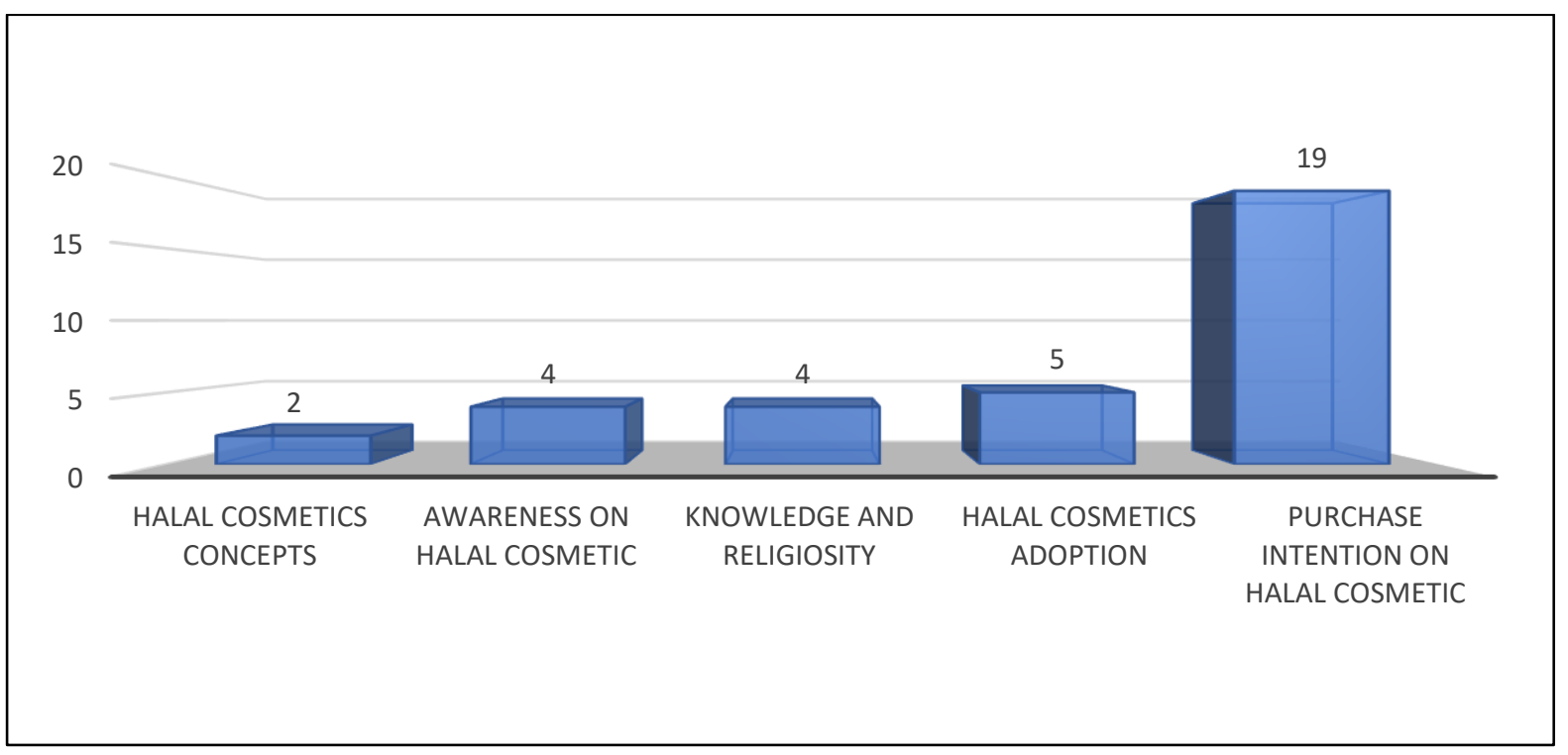

Figure 7: Distribution of reviewed articles by research theme

2. Knowledge and Religiosity

These four studies in terms of knowledge and religiosity of halal cosmetic are one of the halal cosmetic studies' themes. There was a study related to knowledge and religiosity of consumers and companies towards halal cosmetics. According to Aoun and Tournois (2015), even though marketing practices, religion, and consumption intersect, it is largely unexplored, but some brands integrate religious concerns into their strategies through Halal branding. As stated by Yeo and Mohamed (2017), the companies that generate strong emotional associations with customers can fulfil and capture their unconscious feelings. This is because the emotionally connected customers will be more motivated to continue buying from the company that generates Halal cosmetics.

\section{Awareness of Halal Cosmetic}

Halal awareness among consumers and governments is particularly high. However, the demand for halal cosmetics and beauty products is not so strong. With consumer awareness and willingness to purchase quality products, this situation changes, thereby transforming the cosmetics and personal care industry into a potential emerging market in the region. According to Mustafar et al (2018b), the cosmetics manufacturer's awareness of halal cosmetics is important due to the demand for halal cosmetics. Meanwhile, based on a study by Derasit et al (2020), there is no guarantee that customers fully understand the existence of halal cosmetics, especially among young people. Therefore, the factors that affect the level of awareness need to be determined. The study identified four factors to 
influence young consumers and Malaysians' level of awareness on halal cosmetics: Halal certification, promotion, level of belief, and religiosity.

\section{Halal Cosmetics Adoption}

In the current millennium, the demand for halal cosmetics has grown strongly. The turning point for the increase in demand is the increase in the Muslim population and consumer demand for safety, hygiene, and human beauty products. However, due to various factors, the halal cosmetics industry has been unable to meet its customers' needs. Therefore, according to Mohezar et al (2016), factors that motivate young adult Muslim consumers in emerging markets to adopt halal cosmetics are perceived product characteristics, social influence, and consumer innovation ability. Despite that, in terms of the cosmetic manufacturer, the implementation of quality control methods aimed at improving the quality of halal products has become an organization's business strategy (Yusoff et al., 2015). This is because, due to having safety and non-hazardous for customer use, the manufacturer needs to adopt the high-quality process in the manufacturing. In addition, financial cost and social influence also affect the adoption of halal cosmetics (Ali et al., 2019).

\section{Halal Cosmetic Concept}

Despite that, 2 out of 34 articles were focused on the halal cosmetics concept. According to Annabi and Ibidapo-Obe (2017), the halal cosmetics concept refers to decisionmaking, which is affected by the aware effort to reduce the risk based on consumers' culture and Islam. The halal concept in their study was focused on halal certification of halal cosmetics particularly on how halal certification is given out by the halal authority; JAKIM in Malaysia. The certification is a symbol of the quality of the product that meets the Syariah criteria. Other than that, the study from Mohammadian and Hajipour (2016) discussed the concept of the halal cosmetics supply chain which is focused on the traceability system. This system is used to track and trace the product to assure the product meets the Islamic guidelines. The study also stated that the concept of halal cosmetic is related to the controlled elements of halal quality while the effects of halal policy are based on the different parts of halal cosmetics.

\section{Discussion and Future Research Direction}

This study has attempted to systematically analyse the existing literature on the halal cosmetics industry. The halal cosmetics industry has a significant ability to promote the development of the halal economy. Halal involves brand elements and the belief system and ethical code of conduct in our daily lives. Therefore, a rigorous review from two databases has resulted from 34 related articles on the halal cosmetics industry. The result indicates that purchase intention is the most famous theme between awareness on halal cosmetics, halal cosmetics adoption, knowledge and religiosity and halal cosmetics concept.

According to Hussin et al (2013b), consumers' purchase intentions can be determined by five factors: brand, price, quality, ingredients, and label. The research showed a significant positive correlation between each product factor and the willingness to buy halal products other than the brand. Consumers are willing to pay higher prices for halal products. Nevertheless, the study also showed that consumers are willing to pay for halal products due to their quality. This is because they believe that halal products are of good quality and can be used safely. Arbak et al (2019b), found that there was a significant 
relationship between advertising and halal cosmetics. Advertising is related to honesty, racism, sexism, language, and intentions. In their study, four Islamic advertising moral violation factors (racism, sexism, intention, and language) are statistically significant in influencing the intent to purchase halal cosmetics in Malaysia. A factor that violates Islamic advertising ethics has no significant impact on Malaysia's willingness to buy halal cosmetics. Among four factors, sexism is the strongest factor that influences consumer purchase intention.

The other themes of halal cosmetics adoption, awareness of halal cosmetics, and knowledge and religiosity are the least themes investigated for the past ten years. For halal cosmetics adoption, Ali et al (2019) in their study stated that financial cost and social influence are the most crucial part for the manufacturer to adopt the halal process. This is because halal cosmetics are new and need many things to implement the strategy. For example, the cost needed to buy a new machine and influencing the society with halal products. As for awareness on halal, there two awareness involved which are consumed and manufacturer awareness. Based on the study by Mustafar et al (2018a), it focused on manufacturer awareness of halal products. The study stated there is still a lack of awareness from manufacturers to produce halal cosmetics products. Meanwhile, the study on the theme of knowledge and religiosity focused many on consumers' perspectives and companies' ability towards producing halal cosmetics. The study stated that the consumer who knows the product is willing to pay for halal cosmetics because they know about its quality (Aoun \& Tournois, 2015). In terms of company knowledge about halal cosmetics, brands integrate religious concerns into their halal branding strategies due to the high demand. Lastly, it is the halal cosmetics concepts. A study by Mohammadian and Hajipour (2016) stated that many research on halal cosmetics concepts is discussed on the issues related to the controlled elements of halal quality and the effects of halal policy on the different parts of halal cosmetic.

Although the demand for halal cosmetics is increasing, there are still some unknowns about halal cosmetics. Therefore, it requires more attention on several research areas. According to the prior literature, most of the current articles are completely quantitative (24) studies, nine are qualitative studies, and one is a mixed-method study. Thus, it is suggested that future research should focus more either qualitative or mixedmethod design. It is necessary to understand how and why organizations adopt and implement halal cosmetics, and it is important to conduct more case studies or phenomenology and other inductive methods or interpretive paradigms. Through qualitative design, halal cosmetics will be deeply explored, and more new insights are obtained.

\section{Conclusion}

The PRISMA Statement (Preferred Reporting Items for Systematic reviews and MetaAnalyses) review method was employed to categorize the articles from the year 2010 to 2020. The finding of this study indicated that halal cosmetics articles were highly published in the year 2019 due to higher consumer spending on halal cosmetics. Another finding revealed that the highest publication was conducted in Malaysia. The possible reason is that Malaysia is the earliest country which had awareness of halal product compared to other countries in the world. Furthermore, the study also found that the most common theory applied for halal cosmetics articles is the Theory of Planned Behaviour (TPB). The possible reason might be that most of the articles are interested to study about the level of adoption 
of halal cosmetic products among the consumers and customers purchase intention. On top of that, thematic analysis was applied, and five main themes were generated which included purchase intention on halal cosmetics, halal cosmetics adoption, awareness of halal cosmetics, knowledge and religiosity, and halal cosmetics concept. Quantitative type of study was found to be the most common type of research design in halal cosmetic research domain and Journal of Islamic Marketing was the popular journal with the highest publications on halal cosmetics since 2010.

\section{Acknowledgement}

We would like to express our gratitude to the Universiti Teknologi MARA (UiTM) Research Management Centre (RMC) for providing the Geran Inisiatif Penyelidikan (600-RMC/GIP 5/3 (066/2021).

\section{References}

Abd Rahman, A., Asrarhaghighi, E., \& Ab Rahman, S. (2015). Consumers and halal cosmetic products: Knowledge, religiosity, attitude and intention. Journal of Islamic Marketing. 6(1), 148-163. https://doi.org/10.1108/JIMA-09-2013-0068

Abdullah, N., Nuruddin, H. N., \& Abdullah, A. (2020). Determinants of the Halal Cosmetics Adoption among Young Consumers in the Klang Valley. Journal of Islam and the Contemporary World, 55-83.

Ali, Q., Salman, A., Yaacob, H., \& Parveen, S. (2019). Financial cost and social influence: Factors affecting the adoption of Halal cosmetics in Malaysia. Academy of Entrepreneurship Journal, 25(2), 1-17.

Ali, S., Halim, F., \& Ahmad, N. (2016). The state of halal cosmetic research on consumer behavior: A systematic review of the literature and future research directions. Journal of Marketing Management and Consumer Behavior, 1(4), 40-51.

Annabi, C. A., \& Ibidapo-Obe, O. O. (2017). Halal certification organizations in the United Kingdom: An exploration of halal cosmetic certification. Journal of Islamic Marketing, 8(1), 107-126.

Aoun, I., \& Tournois, L. (2015). Building holistic brands: An exploratory study of halal cosmetics.Journal of Islamic Marketing, 6(1), 109-132.

Arbak, S., Islam, R., \& Al Rasyid, H. (2019a). Influence of islamic advertising: Ethic violation on customer purchase intention of halal cosmetic products in Malaysia. Humanities and Social Sciences Reviews, 7(3), 671-682.

Arbak, S., Islam, R., \& Al Rasyid, H. (2019b). Relationship between advertisement and purchase intention on halal cosmetic products in Malaysia. Humanities and Social Sciences Reviews, 7(3), 683-694.

Briliana, V., \& Mursito, N. (2017). Exploring antecedents and consequences of Indonesian Muslim youths' attitude towards halal cosmetic products: A case study in Jakarta. Asia Pacific Management Review, 22(4), 176-184.

Clarita, N. A., Zimbalist, S. B., \& Setiowati, R. (2020). Factors Impacting Customer Attitude toward Buying Halal Cosmetics in Jabodetabek. The Winners, 7-13.

Daud, N. M., Aziz, H. A., Baharudin, N. H., \& Shamsudin, S. F. (2012). Identifying the determinant attributes of halal cosmetics product that influence its positioning strategy in Malaysian market. Journal of Applied Sciences Research, 8(1), 301-313. 
Derasit, Z., Shariff, S. S. R., Hamid, N. A. A., Sarwani, N., \& Shaharuddin, W. N. S. (2020). Exploratory factor analysis in determining consumer awareness toward halal cosmetics. Malaysian Journal of Consumer and Family Economics, 24 (S2).

Durach, C. F., Wieland, A., \& Machuca, J. A. (2014). Antecedents and Dimensions of supply chain robustness: a systematic literature revkiew. International Journal of Physical Distribution \& Logistics, Vol. 45 Iss 1/2 pp. 118 - 137.

Global Halal Cosmetics Market to Garner \$54.16 Billion by 2022. (2021). Allied Market Research.

https://www.globenewswire.com/news release/2021/04/01/2203745/0/en/Global- Halal-Cosmetics-Market-to-Garner-54-16Billion-by-2022-Allied-Market-Research.html

Handriana, T., Yulianti, P., Kurniawati, M., Arina, N. A., Aisyah, R. A., Ayu Aryani, M. G., \& Wandira, R. K. (2020). Purchase behavior of millennial female generation on Halal cosmetic products. Journal of Islamic Marketing, 11(6).

Haque, A., Anwar, N., Tarofder, A. K., Ahmad, N. S., \& Sharif, S. R. (2018). Muslim consumers' purchase behavior towards halal cosmetic products in Malaysia. Management Science Letters, 8, 1305-1318.

Husain, R., Abd Ghani, I., Mohammad, F., \& Mehad, S. (2012). Current Practices among Halal Cosmetics Manufacturers in Malaysia. Journal of Statistical Modeling and Analytic, 3(1), 46- 51.

Husain, R. B. (2015). Implementation of statistical process control by management in cosmetic production organization: Case of halal cosmetics companies in selangor. International Journal of Applied Business and Economic Research, 13(7), 5899-5919.

Husain, R., Sarifah Radiah Shariff, S., \& Zahari, S. M. (2019). Modelling the effects of statistical process control implementation on halal cosmetics products. Malaysian Journal of Consumer and Family Economics, 23, 1-22.

Hussin, S. R., Hashim, H., Yusof, R. N., \& Alias, N. N. (2013a). Relationship between product factors, advertising, and purchase intention of Halal cosmetic. Pertanika Journal of Social Science and Humanities, 21(SI), 85-100.

Hussin, S. R., Hashim, H., Yusof, R. N., \& Alias, N. N. (2013b). Relationship between product factors, advertising, and purchase intention of Halal cosmetic. Pertanika Journal of Social Science and Humanities, 21(SI), 85-100.

Ismail, R. M., Razalli, M. R., \& Sin, M. A. M. (2019). The search of best practices of Malaysian halal cosmetics industry to improve firm performance. International Journal of Islamic Marketing and Branding, 4(3/4), 212-227.

Jamil, A., Rahman, S. A., \& Fakhriyah, A. (2020). A study on consumer purchase intention towards halal cosmetics and personal care products in selangor, malaysia. International Journal of Pharmaceutical Research, 12(3), 2012-2023.

Jihan, A., Mohd, C., \& Musa, R. (2016). Proceedings of the 1st AAGBS International Conference on Business Management 2014 (AiCoBM 2014). Proceedings of the 1st AAGBS International Conference on Business Management 2014 (AiCoBM 2014), pp. 93-100.

Kaur, K., Osman, S., Kaur, S., \& Singh, J. (2018). Is Halal a priority in purchasing cosmetics in Malaysia among Muslim Malaysian women? International Journal of Business, Economics and Law, 15(3), 19-25.

Khalid, N. R. B., Wel, C. A. B. C., Alam, S. S., \& Mokhtaruddin, S. A. B. (2018). Cosmetic for Modern Consumer: The Impact of Self-Congruity on Purchase Intention. International Journal of Asian Social Science, 8(1), 34-41. 
Khan, N., Sarwar, A., \& Tan, B. C. (2020). Determinants of purchase intention of halal cosmetic products among Generation $Y$ consumers. Journal of Islamic Marketing, 11(6).

Mahmud, M., Shah Nawaz, M., Jamal, A., Sabir, I., Bilal Majid, M., Rehman, U. A., \& Mahmood, H. (2020). Purchase of Halal Products and Consumer Behavioral Intentions: A Systematic Literature Review. International Journal of Disaster Recovery and Business Continuity, 11(3), 1403-1411.

Maichum, K., Parichatnon, S., \& Peng, K. C. (2016). Application of the extended theory of planned behavior model to investigate purchase intention of green products among Thai consumers. Sustainability (Switzerland), 8(10), 1077.

Mohamed, R. N., \& Li, Y. B. (2017). Interdependence between social value, emotional value, customer experience and customer satisfaction indicators: The case of halal cosmetics industry in Malaysia. Pertanika Journal of Social Sciences and Humanities, 25(February), 131-142.

Mohammadian, F., \& Hajipour, B. (2016). Halal cosmetics supply chain - A conceptual model. International Journal of Supply Chain Management, 5(1), 33-43.

Mohezar, S., Zailani, S., \& Zainuddin, Z. (2016). Halal cosmetics adoption among young Muslim consumers in Malaysia: Religiosity concern. Global Journal Al-Thaqafah, 6(1), 47-59.

Mustafar, M., Ismail, R. M., Othman, S. N., \& Abdullah, R. (2018a). A study on Halal cosmetic awareness among Malaysian cosmetics manufacturers. International Journal of Supply Chain Management, 7(5), 492-496.

Mustafar, M., Ismail, R. M., Othman, S. N., \& Abdullah, R. (2018b). A study on Halal cosmetic awareness among Malaysian cosmetics manufacturers. International Journal of Supply Chain Management, 7(5), 492-496.

Nawaz, M. S., Mahmud, M. S., Nasir, M., Mansha, I., Sabir, I., Majid, M. B., \& Nawaz, F. (2021). A Study on Muslim Younger Generation's Behavioral Intentions towards Purchasing of Halal Cosmetic Products in Pakistan. 27(1), 1660-1675.

Ngah, A. H., Gabarre, S., Han, H., Rahi, S., Al-Gasawneh, J. A., \& Park, S. H. (2021). Intention to purchase halal cosmetics: Do males and females differ? a multigroup analysis. Cosmetics, 6(3).

Ngah, A. H., Ramayah, T., Ali, M. H., \& Khan, M. I. (2019). Halal transportation adoption among pharmaceuticals and comestics manufacturers. Journal of Islamic Marketing, November, 14(6), 103-116.

Ngah, A. H., Thurasamy, R., Aziz, N. A., Ali, M. H., \& Khan, M. I. (2019). Modelling the adoption of halal warehousing services among halal pharmaceutical and cosmetic manufacturers. Journal of Sustainability Science and Management, 14(6), 103-116.

Petticrew, M., \& Roberts, H. (2006). Systematic Reviews in the Social Sciences: A Practical Guide. Oxford: Blackwell, 352.

Putri, T. U., \& Abdinagoro, S. B. (2018). Response to a New Wave in Digital marketing: Does beauty blogger involvement the most influencing factor in halal cosmetic purchase intention. International Journal of Supply Chain Management, 7(6), 446-452.

Putri, T. U., Mursitama, T. N., Furinto, A., \& Abdinagoro, S. B. (2019). Does mui halal logo matter for young millennials? An experiment study in cosmetic mass-market brand. International Journal of Scientific and Technology Research, 8(9), 888-890. 
Sama, R., \& Trivedi, J. P. (2019). Factors affecting consumers' loyalty towards halal cosmetics: An emerging market perspective. International Journal of Business and Emerging Markets, 11(3), 254-273.

Shaffril, H.A.M., Abu Samah, A., D'Silva, J.L., 2017. Adapting towards climate change impacts:Strategies for small-scale fishermen in Malaysia. Mar. Policy 81 (March): 196201.

Shahid, S., Ahmed, F., \& Hasan, U. (2018). A qualitative investigation into consumption of halal cosmetic products: the evidence from India. Journal of Islamic Marketing, 9(3), 484-503.

Sierra-Correa, P.C., Cantera Kintz, J.R., 2015. Ecosystem-based adaptation for improving coastal planning for sea-level rise: a systematic review for mangrove coasts. Mar.mPolicy 51:385-393.

Sudarsono, H., \& Nugrohowati, R. N. I. (2020). Determinants of the Intention to Consume Halal Food, Cosmetics and Pharmaceutical Products. Journal of Asian Finance, Economics and Business, 7(10), 831-841.

Suhartanto, D., Dean, D., Sarah, I. S., Hapsari, R., Amalia, F. A., \& Suhaeni, T. (2020). Does religiosity matter for customer loyalty? Evidence from halal cosmetics. Journal of Islamic Marketing, 11(2).

Sukesi, \& Hidayat, A. W. G. P. (2019). Managing the Halal industry and the purchase intention of Indonesian Muslims the case of Wardah cosmetics. Journal of Indonesian Islam, 10(6).

Suparno, C. (2020). Online purchase intention of halal cosmetics: S-O-R framework application. Journal of Islamic Marketing, 11(1).

Wei, C. Y., Mohamad, Z. Z., \& Kuah, Y. C. (2020). Determinants of Intention to Purchase Halal Cosmetic Products: A Study on Muslim Women in West Malaysia. JOURNAL OF HALAL INDUSTRY \& SERVICES, 3(1).

Yeo, B. L., \& Mohamed, R. H. N. (2017). Islamic marketing on halal cosmetics: From the perspective of motivational emotion of peer pressure on customer retention. Advanced Science Letters, 23(8).

Yeo, B. L., Mohamed, R. H. N., Ismail, S., Rahman, M. K. B. A., \& Shahid, S. A. M. (2018). Customer delight measurement in Halal cosmetics industry in Malaysia: The relationship between functional values, epistemic values and customer emotions towards customer delight. International Journal of Supply Chain Management, 7(5), 267-271.

Yusoff, F. A. M., Yusof, R. N. R., \& Hussin, S. R. (2015). Halal food supply chain knowledge and purchase intention. International Journal of Economics and Management, 9, 155 172.

Zaki, K., Nopiah, R., Walid, A., \& Putra, E. P. (2021). The Role of Environment in Responding to Halal Skincare Products in Indonesia. IOP Conference Series: Earth and Environmental Science, 1796(1).

Zulkifli, N. S., \& Rahman, A. A. (2019). Halal cosmetics: External pressures to adopt Halal certification. Global Journal Al-Thaqafah, 6(1). 